\title{
Editorial
}

\section{Adipose Stem Cells: From Bench to Bedside}

\author{
Giuseppe A. Ferraro, ${ }^{1}$ Hiroshi Mizuno, ${ }^{2}$ and Norbert Pallua ${ }^{3}$ \\ ${ }^{1}$ Multidisciplinary Department of Medical-Surgical and Dental Specialties, Second University of Naples, 80138 Naples, Italy \\ ${ }^{2}$ Department of Plastic and Reconstructive Surgery, Juntendo University School of Medicine, Tokyo 1138421, Japan \\ ${ }^{3}$ Department of Plastic Surgery, Reconstructive and Hand Surgery, Burn Center, RWTH University Hospital Aachen, \\ 52062 Aachen, Germany \\ Correspondence should be addressed to Giuseppe A. Ferraro; gaferraro@libero.it
}

Received 28 February 2016; Accepted 28 February 2016

Copyright (C) 2016 Giuseppe A. Ferraro et al. This is an open access article distributed under the Creative Commons Attribution License, which permits unrestricted use, distribution, and reproduction in any medium, provided the original work is properly cited.

Stem cell biology plays an important role in promoting cellbased treatment. Adult mesenchymal stem cells (MSCs) are derived from various tissues including bone marrow [1], adipose tissue [2], dental pulp [3], and Wharton jelly [4]. When compared to bone marrow mesenchymal stem cells (BMMSCs), adipose tissue represents an ideal source for multipotent progenitors in adults [5]. Adipose stem cells (ASCs) share many characteristics with BM-MSCs, including extensive proliferation and the ability to undergo multilineage differentiation [6] (like bone marrow MSCs, they can differentiate in vitro into adipogenic, osteogenic, chondrogenic, and myogenic cells when cultured in specific lineage-inducing culture media and into endothelial cells), and they display a noticeable plasticity both in vitro and in vivo. Moreover, the high abundance of adipose tissue within the body, its high surgical accessibility, and the demonstrated multipotency of ASCs show adipose tissue as a promising candidate for MSCs harvest and increase the interest in its use in tissue repair, regenerative medicine, and degenerative disease management [7].

ASCs have been studied widely since stem cell investigations emerged in 2001 [8]. Since then, knowledge of their characterization, immunological characteristics, and potential of multilineage differentiation has increased considerably [9-18]. Many international medical conferences have emphasized the importance of ASCs and the International Federation of Adipose Therapeutics and Science (IFATS) has been extremely active in promoting the study and discussion of ASCs [19].
Many surgical strategies for tissue loss replacement initially focused on the historical maxim "replace tissue with like-tissue" procedure. In more recent years, several allogenic and alloplastic materials have been developed and used for tissue repair [20-22]. Current research aims to reduce concerns such as foreign-body reactions, rapid degradation, and risk of immunogenicity.

The development of regenerative medicine strategies requires an appropriate cell source and scaffold, "smart" biomaterials (novel "intelligent" biomaterials with appropriate physical properties able to support in vivo the commitment of adipose stem cells), and a suitable microenvironment to provide the cues and signals for cell growth and tissue formation. Biomaterials are able to direct and organize the cellular events involved in the regenerative process in situ [23, 24]. ASCs are undifferentiated cells with the ability to self-renew and differentiate into different types of specialized cells with a regenerative potential even if not combined with biomaterials. The proliferation and differentiation of adipose stem cells can be regulated biochemically, as well as through the physical properties of microenvironments, such as the topography of the scaffolds, the "stiffness," and mechanical forces.

The potential of adipose stem cell therapies and regenerative medicine is effective and challenging, offering the possibility of tissue repair and replacement in tissue defects related to congenital diseases, trauma, and cancer [25].

This special issue has examined the importance of "adipose stem cells" focusing on the basic biology and potential 
role of ASCs in the treatment and regeneration of cells, tissues, and organs.

\section{Acknowledgments}

We would like to thank Dr. Francesco De Francesco, researcher and plastic surgeon, for his scientific support for the realization of the special issue. It is with honour that we acknowledge the participation of international investigators that have submitted original research and review articles to contribute to the evolving research field of adipose stem cell-biomaterial interactions and the development of clinically effective tissue engineering strategies.

Giuseppe A. Ferraro Hiroshi Mizuno Norbert Pallua

\section{References}

[1] P. Charbord, E. Livne, G. Gross et al., "Human bone marrow mesenchymal stem cells: a systematic reappraisal via the genostem experience," Stem Cell Reviews and Reports, vol. 7, no. 1, pp. 32-42, 2011.

[2] F. De Francesco, G. Ricci, F. D’Andrea, G. F. Nicoletti, and G. A. Ferraro, "Human adipose stem cells: from bench to bedside," Tissue Engineering Part B: Reviews, vol. 21, no. 6, pp. 572-584, 2015.

[3] S. Gronthos, "The therapeutic potential of dental pulp cells: more than pulp fiction?" Cytotherapy, vol. 13, no. 10, pp. 11621163, 2011.

[4] I. Kalaszczynska and K. Ferdyn, "Wharton's jelly derived mesenchymal stem cells: future of regenerative medicine? Recent findings and clinical significance," BioMed Research International, vol. 2015, Article ID 430847, 11 pages, 2015.

[5] M. Strioga, S. Viswanathan, A. Darinskas, O. Slaby, and J. Michalek, "Same or not the same? Comparison of adipose tissue-derived versus bone marrow-derived mesenchymal stem and stromal cells," Stem Cells and Development, vol. 21, no. 14, pp. 2724-2752, 2012.

[6] P. A. Zuk, M. Zhu, P. Ashjian et al., "Human adipose tissue is a source of multipotent stem cells," Molecular Biology of the Cell, vol. 13, no. 12, pp. 4279-4295, 2002.

[7] J. M. Gimble, A. J. Katz, and B. A. Bunnell, "Adipose-derived stem cells for regenerative medicine," Circulation Research, vol. 100, no. 9, pp. 1249-1260, 2007.

[8] P. A. Zuk, M. Zhu, H. Mizuno et al., "Multilineage cells from human adipose tissue: implications for cell-based therapies," Tissue Engineering, vol. 7, no. 2, pp. 211-228, 2001.

[9] M. Wosnitza, K. Hemmrich, A. Groger, S. Gräber, and N. Pallua, "Plasticity of human adipose stem cells to perform adipogenic and endothelial differentiation," Differentiation, vol. 75, no. 1, pp. 12-23, 2007.

[10] F. D’Andrea, F. De Francesco, G. A. Ferraro et al., "Largescale production of human adipose tissue from stem cells: a new tool for regenerative medicine and tissue banking," Tissue Engineering C: Methods, vol. 14, no. 3, pp. 233-242, 2008.

[11] A. De Rosa, F. De Francesco, V. Tirino et al., "A new method for cryopreserving adipose-derived stem cells: an attractive and suitable large-scale and long-term cell banking technology,"
Tissue Engineering Part C: Methods, vol. 15, no. 4, pp. 659-667, 2009.

[12] F. De Francesco, V. Tirino, V. Desiderio et al., "Human $\mathrm{CD} 34^{+} / \mathrm{CD} 90^{+}$ASCs are capable of growing as sphere clusters, producing high levels of VEGF and forming capillaries," PLoS ONE, vol. 4, no. 8, Article ID e6537, 2009.

[13] H. Mizuno, "Adipose-derived stem and stromal cells for cellbased therapy: current status of preclinical studies and clinical trials," Current Opinion in Molecular Therapeutics, vol. 12, no. 4, pp. 442-449, 2010.

[14] D. Cholewa, T. Stieh, A. Schellenberg et al., "Expansion of adipose mesenchymal stromal cells is affected by human platelet lysate and plating density," Cell Transplantation, vol. 20, no. 9, pp. 1409-1422, 2011.

[15] H. Orbay, M. Tobita, and H. Mizuno, "Mesenchymal stem cells isolated from adipose and other tissues: basic biological properties and clinical applications," Stem Cells International, vol. 2012, Article ID 461718, 9 pages, 2012.

[16] N. Pallua, M. Serin, and T. P. Wolter, "Characterisation of angiogenetic growth factor production in adipose tissuederived mesenchymal cells," Journal of Plastic Surgery and Hand Surgery, vol. 48, no. 6, pp. 412-416, 2014.

[17] G. F. Nicoletti, F. De Francesco, F. D’Andrea, and G. A. Ferraro, "Methods and procedures in adipose stem cells: state of the art and perspective for translation medicine," Journal of Cellular Physiology, vol. 230, no. 3, pp. 489-495, 2015.

[18] M. Tobita, S. Tajima, and H. Mizuno, "Adipose tissue-derived mesenchymal stem cells and platelet-rich plasma: stem cell transplantation methods that enhance stemness," Stem Cell Research and Therapy, vol. 6, p. 215, 2015.

[19] P. Bourin, B. A. Bunnell, L. Casteilla et al., "Stromal cells from the adipose tissue-derived stromal vascular fraction and culture expanded adipose tissue-derived stromal/stem cells: a joint statement of the International Federation for Adipose Therapeutics and Science (IFATS) and the International Society for Cellular Therapy (ISCT)," Cytotherapy, vol. 15, no. 6, pp. 641648, 2013.

[20] K. Hemmrich, K. Van de Sijpe, N. P. Rhodes et al., "Autologous in vivo adipose tissue engineering in hyaluronan-based gels-a pilot study," Journal of Surgical Research, vol. 144, no. 1, pp. 8288, 2008.

[21] G. A. Ferraro, F. De Francesco, G. Nicoletti et al., "Human adipose $\mathrm{CD} 34^{+} \mathrm{CD} 90^{+}$stem cells and collagen scaffold constructs grafted in vivo fabricate loose connective and adipose tissues," Journal of Cellular Biochemistry, vol. 114, no. 5, pp. 1039-1049, 2013.

[22] Z. Alharbi, S. Almakadi, C. Opländer, M. Vogt, H.-O. Rennekampff, and N. Pallua, "Intraoperative use of enriched collagen and elastin matrices with freshly isolated adipose-derived stem/stromal cells: a potential clinical approach for soft tissue reconstruction," BMC Surgery, vol. 14, no. 1, article 10, 2014.

[23] E. Bressan, A. Carraro, L. Ferroni et al., "Nanotechnology to drive stem cell commitment," Nanomedicine, vol. 8, no. 3, pp. 469-486, 2013.

[24] A. Casadei, R. Epis, L. Ferroni et al., "Adipose tissue regeneration: a state of the art," Journal of Biomedicine and Biotechnology, vol. 2012, Article ID 462543, 12 pages, 2012.

[25] M. Alperovich, Z.-H. Lee, P. L. Friedlander, B. G. Rowan, J. M. Gimble, and E. S. Chiu, "Adipose stem cell therapy in cancer reconstruction: a critical review," Annals of Plastic Surgery, vol. 73, supplement 1, pp. S104-S107, 2014. 

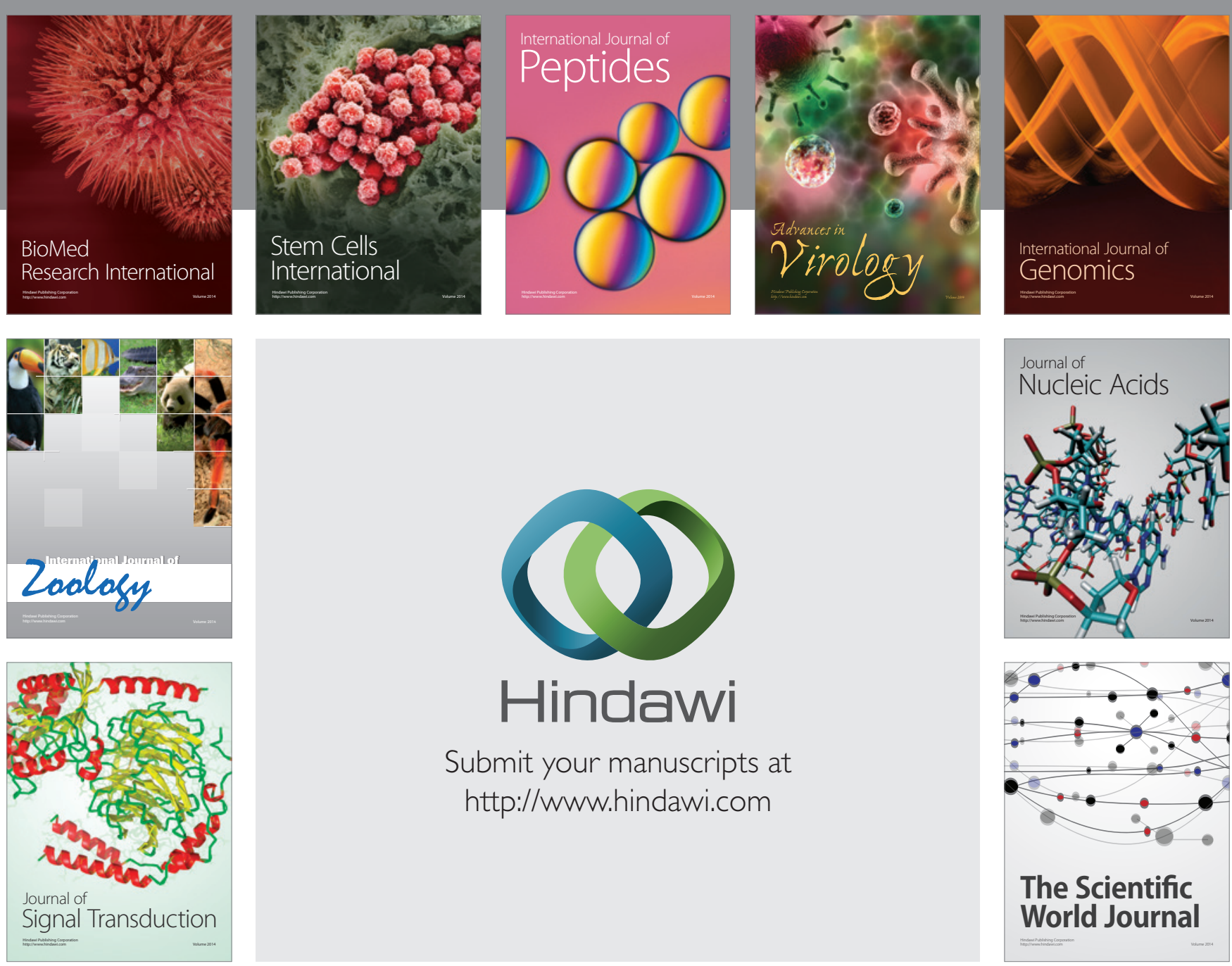

Submit your manuscripts at

http://www.hindawi.com
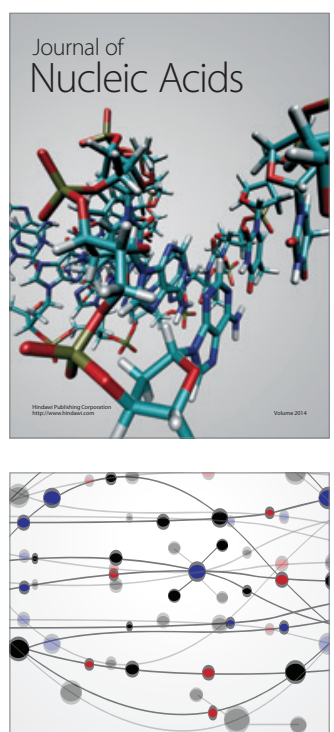

The Scientific World Journal
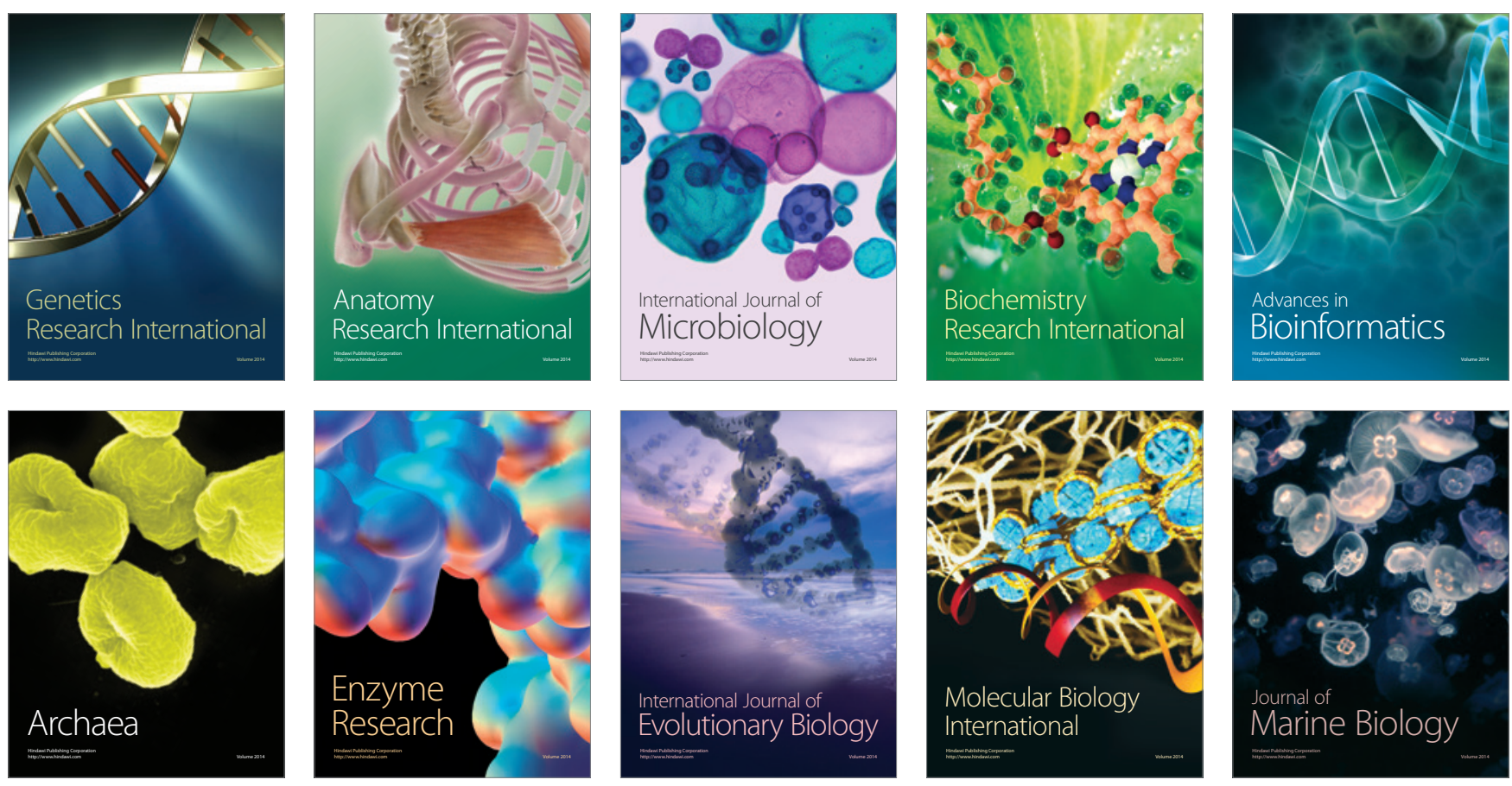